\title{
Business Human Rights Responsibility for Refugees and Migrant Workers: Turning Policies into Practice in the Middle East
}

\author{
Samentha GOETHALS*, Joe BARDWELL**, Mariam BHACKER*** and \\ Bahaa EZZELARAB****
}

Keywords: benchmarking, due diligence, Middle East, migrant workers, Syrian refugees

\section{INTRODUCTION}

Global business plays an intrinsic role in the experience of migrants and refugees. It is a generator of migration flows, an employer, and a provider of goods and services. Business also derives benefits from refugees and migrant workers, including entrepreneurship, innovation and their often cheaper labour. ${ }^{1}$ While the private sector does not have the same obligations and capacities as States to protect and provide for refugees and asylum seekers, it is a fundamental actor in addressing the human rights and labour risks posed by growing migration and refugee flows. ${ }^{2}$ The impacts and responsibility of business on human rights are apparent in the United Nations Guiding Principles on Business and Human Rights (UNGPs), ${ }^{3}$ and in recent legislation on modern slavery that requires companies to set out policies and implement processes to address issues such as forced labour, child labour, human trafficking and other forms of

\footnotetext{
* Senior Researcher on Labour Rights, Business and Human Rights Resource Centre, email: goethals@businesshumanrights.org (main contact)

** Corporate Accountability \& Communications Officer, Business and Human Rights Resource Centre, email: bardwell@business-humanrights.org

*** Project Manager - Migrant Workers and Gulf Business, Business and Human Rights Resource Centre, email: bhacker@business-humanrights.org

**** Middle East \& North Africa Researcher \& Representative, Business and Human Rights Resource Centre, email: ezzelarab@business-humanrights.org

1 Business and Human Rights Resource Centre (BHRRC), 'Submission to the UN Summit for Refugees and Migrants - The private sector, refugees and migrants: a human rights approach' (2016) https://business-humanrights. org/de/node/140560 (accessed 14 March 2017); Alexander Betts, Louis Bloom and Nina Weaver, Refugee innovation: Humanitarian innovation that starts with communities, Humanitarian Innovation Institute, University of Oxford, 2015; Max Nathan and Neil Lee, 'Cultural Diversity, Innovation, and Entrepreneurship: Firm-level Evidence from London' (2013) 89:4 Economic Geography 367.

2 Steven A Zyck and Randolph Kent, 'Humanitarian crises, emergency preparedness and response: the role of business and the private sector - Final report' (Overseas Development Institute, 2014); Regina Sheyvens, Glenn Banks and Emma Hughes, 'The Private Sector and the SDGs: The Need to Move Beyond "Business as Usual"' (2016) 24:6 Sustainable Development 371.

3 Human Rights Council, 'Guiding Principles on Business and Human Rights: Implementing the United Nations "Protect, Respect and Remedy” Framework', A/HRC/17/31 (21 March 2011), II A para 14, p.14.
} 
modern slavery in their operations and supply-chains. ${ }^{4}$ These risks are often exacerbated in high migration contexts. This means that, at a minimum, global companies should pay particular attention to their operations and supply-chains in countries with large migration flows given the enhanced vulnerabilities of refugees and migrant workers.

Our focus in this piece is to consider how companies have been implementing their human rights responsibility to address the risks and challenges faced by refugees and migrant workers in the Middle East, a region that is currently experiencing unprecedented population movements. It draws on two case studies from recent research by the Business and Human Rights Resource Centre (BHRRC) on: (1) migrant construction workers in Qatar and the United Arab Emirates (UAE); and (2) Syrian refugees in garment supply-chains in Turkey.

By adopting a mixed methods research approach that includes fieldwork, company surveys and benchmarking, these cases reveal that there is still a long way to go for global businesses to fulfil their potential to help generate economic security and realize the basic rights of migrant workers and refugees to decent and fair work. In both cases, we found small clusters of leading companies and larger groups of laggards. The piece concludes with a reflection on combining increased transparency with scrutiny and benchmarking to create a 'race to the top', and makes recommendations for human rights due diligence to prevent exploitation and discrimination against refugees and migrant workers.

\section{Migrant Construction Workers in Qatar and the United Arab Emirates}

\section{A. Migration context and issues}

The six countries of the Gulf are a major destination for migrant workers, accounting for over 10 per cent of all migrants globally. ${ }^{5}$ Migration to the Gulf offers migrant workers from less economically developed countries, such as Bangladesh, India, Nepal, Pakistan and the Philippines, improved employment opportunities and higher earning potential. It is estimated that approximately US\$109 billion was remitted from the Gulf to countries of origin in $2014 .^{6}$ In return, countries of destination receive a steady stream of workers to supplement their large labour shortages, with migrant workers accounting for more than 80 per cent of the population in Qatar and the United Arab Emirates (UAE).

Recent research has documented the risks that migrant construction workers face in these countries. These include: excessive debt incurred through high recruitment fees; unequal, late, or non-payment of wages or illegal deductions; treacherous working conditions; denial of freedom of movement; denial of freedom of association and assembly; minimal enforcement of the labour law; and limited or no access to legal and

\footnotetext{
4 California Transparency in Supply-chains Act 2010 (SB 657) (US); Modern Slavery Act 2015 (UK); Proposition de Loi relative au devoir de vigilance des sociétés mères et des entreprises donneuses d'ordre 2017 (FR).

5 The Gulf states comprise: Bahrain, Kuwait, Oman, Qatar, Saudi Arabia and the United Arab Emirates.

6 Hans de Glind, 'Labour Migration in the Arab States' (ILO: 2014) http://www.ilo.org/beirut/areasofwork/labourmigration/WCMS_514910/lang-en/index.htm (accessed 14 March 2017); 'Migration in the Gulf Open doors but different laws', The Economist (8 September 2016) http://www.economist.com/news/middle-east-and-africa/ 21706524-because-migrants-gulf-have-few-rights-locals-let-more-them-open (accessed 14 March 2017).
} 
judicial remedies. Underpinning many of these risks is a labour system based on kafala (sponsorship), which governs the admission, residency, employment and exit of workers. Workers cannot legally seek alternative employment or leave their employer without the employer's permission, and are therefore unable to leave exploitative situations at the risk of being detained or deported. According to the International Labour Organization (ILO) Committee of Experts on the Application of Conventions and Recommendations (CEACR), which is responsible for evaluating the state of application of international labour standards, 'the kafala system may be conducive to the exaction of forced labour'. It has thus requested that 'the governments concerned protect migrant workers from abusive practices'. 7

\section{B. Research approach}

Considering these restrictions and risks to migrant labour and the current construction boom in Qatar for the 2022 FIFA World Cup and World Expo 2020 in Dubai, BHRRC surveyed 100 construction companies operating in Qatar and the UAE on the measures they are taking to prevent the types of abuse listed above. The company responses were published on a searchable, online database and formed the basis of an analysis of action (or lack thereof) from companies to address risks to migrant workers' rights in their operations. $^{8}$

\section{Findings}

The results of our outreach revealed an appalling lack of transparency from the construction sector: the overwhelming majority (78 per cent) of the global multinationals and local subsidiaries we surveyed did not respond. Only 39 per cent had a publicly available commitment to human rights, which reveals an alarming lack of commitment to human rights that goes beyond non-participation in the survey.

In terms of policy and practice, our research revealed a vast gap between a small group of leading companies and a long trail of laggards. We identified examples of meaningful action taken by companies including measures that address exploitative subcontracting and recruitment practices and restrictions on freedom of association. For example, Interserve and Multiplex have developed systems to manage and monitor the employee welfare practices of their subcontractors. Vinci has introduced numerous safeguards in its recruitment chain to prevent workers from paying recruitment fees, and to reimburse them in cases where they have been charged. Salini Impregilo has signed an agreement with Building and Woodworkers International (BWI) and Italian construction unions to promote and respect the fundamental human rights of its workers worldwide, and has allowed BWI to visit its worker accommodation in Qatar where trade union activities are highly restricted.

Conversely, companies involved in the construction of flagship stadiums for Qatar's US $\$ 200$ billion World Cup did not respond, namely Al Balagh Trading \& Contracting, Larsen \& Toubro, HBK Contracting, J\&P Avax SA, Joannou \& Paraskevaides

7 de Glind, ibid.

8 BHRRC, Migrant workers in Gulf construction sector platform (2016b) https://business-humanrights.org/migrantworkers-in-gulf-construction (accessed 14 March 2017). 
(Overseas), Midmac and Porr. With the number of migrant workers building stadiums reportedly set to jump from 5,000 to 36,000 in the next year, this lack of procedural transparency from companies aggravates concerns over their ability to safeguard the rights and safety of a ballooning workforce, especially considering previously documented cases of worker abuse on World Cup sites. ${ }^{9}$

Following publication of the survey, several non-responding companies decided to participate including Bam International, OHL and Al Jaber. In parallel, numerous initiatives around construction and labour rights have emerged including the launch of the Building Research Establishment (BRE) Ethical Labour Sourcing Standard, ${ }^{10}$ a joint programme between Stronger Together and the Chartered Institute of Building aimed at supporting UK construction companies with guidance and resources on modern slavery, ${ }^{11}$ and a global initiative to promote human rights and welfare of workers called 'Building Responsibly'. ${ }^{2}$

\section{Syrian Refugees in the Garment Sector In Turkey}

\section{A. Migration context and issues}

As Western countries scrambled to stop 'the flood of Syrian refugees to Europe' in an attempt to appease the rise of anti-immigration and populist political currents, Turkey, Jordan and Lebanon have become host to most of the Syrian refugees fleeing the protracted war. ${ }^{13}$ Among the 3.5 million refugees living in Turkey, 3.2 million Syrian refugees are now building their lives and futures. ${ }^{14}$ Syrian refugees should be simultaneously considered as 'both refugees fleeing their countries due to civil war, as well as active economic agents looking for opportunities to work or invest. ${ }^{15}$ The World Bank 2015 New Financing Initiative and the international assistance pledges made at the 2016 London Conference 'Supporting Syria and the Region' reflect this perspective. These initiatives seek to create incentives for investment and job creation to allow Syrian refugees to join the labour market in Turkey, Jordan and Lebanon. ${ }^{16}$ The challenge,

\footnotetext{
9 Amnesty International, 'The Ugly side of the beautiful game: Exploitation of workers on a Qatar 2022 World Cup site', (2016) https://www.amnesty.org/en/documents/mde22/3548/2016/en/; 'Qatar population booms on back of 2022 World Cup' France 24 (2 March 2017) http://www.france24.com/en/20170302-qatar-population-booms-back-2022world-cup (accessed 14 March 2017).

10 BRE Group, Sustainability and Environmental Standards, BES 6002 Issue 1 (2017) http://www.greenbooklive. com/filelibrary/ELS/BES-6002-Ethical-Labour-Sourcing-Standard.pdf (accessed 14 March 2017).

11 Stronger Together and Chartered Institute of Buildings, Tackling Modern Slavery in the Construction Sector, (2017) http://stronger2gether.org/construction/ (accessed 14 March 2017).

12 For an archive of articles see BHRRC 'New business coalition, "Building Responsibly", forms to protect workers' rights in construction industry' (27 February 2017) https://business-humanrights.org/en/new-business-coalitionbuilding-responsibly-forms-to-protect-workers-rights-in-construction-industry (accessed 14 March 2017).

13 Alexander Betts and Paul Collier, 'Help refugees help themselves: Let displaced Syrian join the labour market', Foreign Affairs (2015).

14 Emre Eren Korkmaz, 'How do Syrian refugee workers challenge supply-chain management in the Turkish garment industry?', IMI Working Papers Series 133/2017 https://www.imi.ox.ac.uk/publications/how-do-syrian-refugeeworkers-challenge-supply-chain-management-in-the-turkish-garment-industry; 'Türkiye'de kaç milyon mülteci var? Bakan Soylu açıladı', Sozcu 15 February 2017, http://www.sozcu.com.tr/2017/gundem/turkiyede-kac-milyonmulteci-var-bakan-soylu-acikladi-1680764/ (accessed 14 March 2017).

15 Korkmaz, ibid; Betts and Collier, note 13.

16 Andrej Mahecic, 'London Syria Conference: World leaders urged to help Syrians', (UNHCR: 2016) http://www.unhcr.org/uk/news/latest/2016/2/56b1fc4f6/london-syria-conference-world-leaders-urged-help-syrians.html;
} 
however, is for governments, international donors, civil society and companies to ensure that these initiatives result in equal, fair and decent employment for refugees, migrant workers and host communities.

The Turkish clothing industry has been the sixth largest world exporter and third largest exporter to the European Union since 2013. ${ }^{17}$ From late 2015, an increasing number of worrying reports of abuse and exploitation of Syrian refugees in Turkish garment factories emerged. ${ }^{18}$ Exploitation results from the combination of a desperate, vulnerable workforce with little access to legal work, negative perceptions of Syrian refugees among employers, an industry that drives prices down, and a reliance on subcontracting in Turkey. ${ }^{19}$ After concerted lobbying by global brands, the Turkish Government published legislation in January 2016 that allows refugees to gain work permits. This is a first step in improving refugees' participation and protection in formal labour, although significant obstacles remain, such as those described above.

\section{B. Research approach}

In light of this context, BHRRC conducted two surveys with garment companies that produce clothes for Europe's high street shops and source from Turkey. We surveyed 28 companies in the first round in February 2016, and 38 companies in our follow-up outreach in September 2016. Our objectives were: (1) to identify the steps these companies were taking to protect vulnerable refugee workers, and (2) to examine change and progress in company practices. Both surveys covered questions on policy, audits, subcontracting, action to protect refugees, and capacity building. ${ }^{20} \mathrm{We}$ also conducted a short field visit to Istanbul and interviewed Syrian refugees working in garment workshops in July 2016. The company responses were published on a searchable, online database and formed the basis of two briefings tracking the progress of the garment sector in tackling exploitation of refugees in garment supply-chains in Turkey. ${ }^{21}$

\section{Findings}

Our field visit and successive surveys reveal that while exploitation of refugees remains endemic, there have been some positive shifts in the attitude of European high street garment brands. For instance, our interviews with Syrian refugees employed in garment

\section{(F'note continued)}

World Bank, 'International Community Endorses New Initiative to Support Refugees, Host Communities, Recovery and Reconstruction in the Middle-East and North Africa' (15 April 2016) http://www.worldbank.org/en/news/press-release/ 2016/04/15/international-community-endorses-new-initiative-to-support-refugees-host-communities-and-recovery-in-mena (accessed 14 March 2017).

17 Fibre2Fashion, 'Turkey textile industry overview', (2017) http://www.fibre2fashion.com/market-intelligence/ countryprofile/turkey-textile-industry-overview/ (accessed 14 March 2017).

18 For an archive of reports on the issue, see BHRRC, 'Syrian refugees: Abuses and exploitation in Turkish garment factories' (2016) https://business-humanrights.org/en/modern-slavery/syrian-refugees-abuse-exploitation-in-turkishgarment-factories (accessed 14 March 2017).

19 Korkmaz, note 14.

20 For details of the survey, see BHRRC, What's changed for Syrian refugees in the Turkish garment industry? (2016) https://business-humanrights.org/en/syrian-refugees-in-turkish-garment-industry/the-survey (accessed 14 March 2017).

21 The survey was developed with input from the Ethical Trading Initiative, International Trade Union Confederation (ITUC), and Fair Labour Association. 
workshops in Istanbul corroborate reports of child labour and poor working conditions, including payments below the minimum wage and discrimination. ${ }^{22}$ We heard accounts of Syrians refugees earning on average TL700-1,100 a month, about 43-67 per cent of the Gross National Minimum Wage of TL1647. Respondents also described being treated much more harshly for minor transgressions than their Turkish counterparts. We were told that Syrian child labour was widely used in workshops. These children, boys and girls aged between 11 and 14 years, were paid less than Syrian adults, around TL500-600. The interviews also echo Korkmaz's findings regarding the reluctance of Syrian refugees to apply for permits to gain formal employment, and the prejudices of employers against them. These attitudes amongst employers and workers help entrench informal work and reinforce situations of exploitation in the garment industry. Various respondents throughout the study insisted that there is a risk that brands would leave if reputational risks and security concerns undermined the advantages of sourcing quality, low costs and fast manufacture from Turkey. ${ }^{23}$

Only ten of the 28 brands we approached in our first survey responded to our questionnaire, or sent short statements. As of February 2016, few brands had taken decisive actions to tackle risks of exploitation and protect Syrian refugees, such as avoiding child labour (e.g. Next and $\mathrm{H} \& M)$. Others, however, cited zero tolerance policies on the employment of undocumented workers as evidence that they do not exist in their supply-chain.

The follow-up survey returned more detailed responses and revealed a positive shift in action, probably due to the increased media and civil society scrutiny. ${ }^{24}$ For example, half of the garment brands contacted have taken some targeted action to address the risks refugees face, including increased monitoring programmes and collaborative action to stop exploitation. ASOS, C\&A, Esprit, GAP, Inditex, KiK, LC Waikiki, Mothercare, New Look, Next, Otto Group, Primark, Tesco, Tchibo and White Stuff stated that they expect suppliers to support unregistered refugees to get work permits. This is a positive shift given that many brands previously cited a zero-tolerance policy towards unregistered refugees working in factories, leading to their dismissal the worst outcome for their welfare. Next, New Look and Mothercare have gone further, with detailed plans triggered when a refugee is found working in a factory to ensure they are protected and treated fairly. They also pay the minimum wage while Syrians are employed and do not yet have a work permit. This is an important step because it recognizes that unregistered Syrian workers are unable to access social security. Nine brands (up from four brands in our first survey) also reported having identified unregistered Syrian refugees in their supply-chains. This is a positive step towards action to stop exploitation, which demonstrates new openness about this issue.

Disappointingly, however, six brands did not respond to our surveys - Gerry Weber, Lidl, Mexx, New Yorker, River Island and Sainsbury's. A number of other brands (Arcadia, Burberry, S. Oliver, SuperGroup, VF Corp and Walmart) only supplied short statements.

\footnotetext{
22 BHRRC, note 18.

23 For findings of the second survey and field visit, see BHRRC, note 20.

24 In the second survey, 26 out of 38 brands responded or sent short statements ( 68 per cent compared with 38 per cent in the first survey). For more details, see BHRRC, ibid, p.1.
} 


\section{ReFlections AND CONCLUSION}

The two case studies presented here are part of ongoing and expanding research projects at BHRRC. ${ }^{25}$ In both cases, outreach to companies, benchmarking of their policies and reported practices, and publication of their responses on a public platform have contributed to raise awareness of salient risks to refugees and migrant workers in the supply-chains of the garment and construction sectors, respectively. This model complements the initiatives of other civil society organizations to scrutinize company performance and hold them accountable for their reported policies and practices. ${ }^{26}$ It also enables BHRRC and others to rank companies against each other and identify examples of better practice that can be emulated by their trailing counterparts.

The results of our outreach in the Gulf identified a handful of construction companies reportedly taking action on human rights. The risks inherent in the accepted business models and complex supply-chains, however, cannot be resolved by companies acting in isolation: collective industry-wide efforts are needed. As it stands, the current lack of industry transparency limits the ability of companies to tackle shared challenges and progress together based on agreed-upon standards and good practice. The emergence of industry groups is an important first step towards achieving this, and BHRRC's survey model has served as both a prompt and a resource for participating companies. ${ }^{27}$ Investors, business partners and civil society actors should also press for increased transparency from companies, rewarding those that take a responsible approach to the recruitment and employment of migrant workers and drawing attention to company inaction.

In the case of the Turkish garment sector, the great majority of European fashion brands must act faster and more decisively to eliminate abusive exploitation of refugees from their supply-chains. Their standard compliance methods of announced audits of their first-tier suppliers are inadequate; far more rigorous approaches should be adopted. ${ }^{28}$ Furthermore, companies should not cease to source from Turkey; they should stay and develop a sustained, long-term view to ensure decent work opportunities. Systemic change to purchasing practices and monitoring processes will be necessary, however, if initiatives to protect Syrian refugees by individual brands are to succeed. Companies need to pay decent prices and ensure greater certainty and predictability for suppliers, to avoid undeclared sub-contracting to informal factories where the risks are highest.

As a first step, companies sourcing from countries with high numbers of refugees and migrant workers should conduct robust human rights due diligence throughout their

\footnotetext{
25 Besides our work on migrant workers in the construction industry in the Gulf and Syrian refugees in the Turkish garment industry, BHRRC is also developing a similar project on access to fair and decent work for Syrian refugees, migrant workers and host communities in Jordan and Lebanon, https://business-humanrights.org/en/access-to-work-injordan-and-lebanon-for-syrian-refugees-migrant-workers-and-host-populations\#c149337 (accessed 26 April 2017).

26 For instance, Human Rights Watch, 'Building a Better World Cup: Protecting migrant workers in Qatar ahead of FIFA 2022' (2012) https://www.hrw.org/report/2012/06/12/building-better-world-cup/protecting-migrant-workersqatar-ahead-fifa-2022; ITUC, 'Qatar 2022: Re-run the vote' https://www.ituc-csi.org/rerunthevote?lang=en; Amnesty International, 'Qatar World Cup of shame' https://www.amnesty.org/en/latest/campaigns/2016/03/qatar-world-cup-ofshame/ (accessed 14 March 2017).

27 Based on personal conversations and email correspondence with construction company representatives.

28 Genevieve LeBaron and Jane Lister, Ethical Audits and the Supply-chains of Global Corporations (January 2016) SPERI, Briefing 1.
} 
supply-chains to prevent exploitation and discrimination. This involves four steps: assessing actual and potential human rights impacts; integrating and acting on the findings; tracking responses; and communicating about how impacts are addressed. Throughout the process, close consultation with local organizations that have deep expertise on the specific challenges and dynamics on the ground is essential, as is an awareness of the enhanced vulnerabilities of refugees and migrant workers in terms of barriers in accessing fair and decent employment, basic services and judicial remedies. ${ }^{29}$

29 BHRRC (2016), note 1. 